\title{
'N OUDIOVISUELE ANALISE VAN WOORDDEELHERHALINGS BY HAKKELAARS
}

\author{
MAGGI VAN WYK B.A. (LOG) (PRETOR1A) \\ Skoolsielkundige Dienste, Posbus 1360. Kempton Park, 1620.
}

\begin{abstract}
OPSOMMING
'n Oudiovisuele analise van woorddeelherhalings wat in spraakopnames van 18 hakkelaars voorgekom het, is gemaak. Hierdie gedragsvorm is"n belangrike diagnostiese kriterium van hakkelspraak. Buiten die voorkomsfrekwensie is veral ook die aard en plek van voorkoms van onderbrekings belangrike faktore in die diagnose van hakkel. Kliniese waarnemings beklemtoon dat die woorddeelherhalings van hakkelaars van dié van nie-hakkelaars onderskei kan word deur o.a. tempoverskille, onreëlmatigheid, gebrek aan oorgangsformante, die gebruik van die schwa-vokaal en die voorkoms van benaderingsgedrag. Ouditiewe parameters asook spcktrogramme is gebruik om die hipotese te bevestig dat die tempo van woorddeelherhalings verskil van die tempo waarteen die vloteenhede van spraak geuiter word. Ook is hierdie herhalings opmerklik onreëlmatig en het die verlangde oorgangsformante nie by herhalingseenhede voorgekom nie. Dit is egter nie die schwavokaal wat gebruik word nie en dit is onwaarskynlik dat die herhalings dien as benadering tot die verlangde oorgang. Hierdie bevindings is van belang vir die differensiaaldiagnose tussen hakkelspraak en normale onvlotheid.
\end{abstract}

\section{SUMMARY}

An audio-visual analysis was conducted on the repetitions of parts of words which occurred in the recorded speech of 18 stutterers. This behaviour manifestation is an important diagnostic indication of stuttering. Not only the frequency of interruptions, but also their nature and place of occurrence, are important factors in the diagnosis of stuttering. Clinical observations stress that the stutterer's repetitions can be distinguished from those of nonstutterers with relation to differences in tempo, irregularity, lack of formant transitions, the use of the schwa vowel and the occurrence of approximation. Auditory parameters as well as spectrograms were used to confirm the hypothesis that the tempo of repetition of parts of words differs from the tempo at which the fluent units of speech are uttered. These repetitions are also notably irregular and necessary formant transitions do not occur in the case of the units which were repeated. However, it was not the schwa vowel which was used, and it is unlikely that the repetitions served as an approximation of the desired transition. These findings are of importance for the differential diagnosis between stuttered speech and normal nonfluency.

Die bydraes ten opsigte van hakkel in die literatuur skep die indruk van groot meningsverskille en duidelike uiteenlopendheid. Hoewel daar reeds baie beskrywings van hakkel gegee is, bv. die baie omvattende beskrywing deur Wingate, ${ }^{32}$ kom hierdie beskrywings oorwegend daarop neer dat hakkel beskou kan word as onderbrekings in die vlotheid van verbale uiting. Die frekwensie van onderbrekings belemmer kommunikasie, ${ }^{5}$ maar dit blyk ook uit baie beskrywings dat veral die aard en plek van voorkoms van hierdie onderbrekings belangrike faktore in die diagnose van hakkel is. Nie alle onderbrekings van spraakvloei kan as hakkel beskou word nie. 
Vlotspraak is hiërargies-geïntegreerde gedrag: hiërargies, omdat dit opgebou is uit verskillende elemente op die klank-, lettergreep-, woorden sinsvlakke ${ }^{28}$ en geïntegreerd, omdat hierdie elemente so ingeskakel is dat oorgangsvlotheid gemanifesteer word. Hierdie oorgangsvlotheid word egter onderwerp aan aanvaarbare onderbrekings soos pouses, ritmiese patroonvorming, tempoveranderinge, intonasie- en klempatrone en tussenwerpsels wat dui op onstabiliteit op die supramorfemiese vlakke. Beskrywings gegee deur Boehmler, ${ }^{7}$ Webster en Brutten, ${ }^{30}$ Peters en Giles ${ }^{21}$ en Van Riper ${ }^{28}$ dui daarop dat onstabiliteit wat op morfemiese vlakke manifesteer as hakkel gediagnoseer word.

Hoewel hakkel baie meer behels as die definisies gegee deur bg. persone, kan hierdie simptome as die kerngedrag van hakkel beskou word. Webster en Brutten ${ }^{30}$ skryf die meningsverskille toe aan die konglomeraat van gedragsvorme wat voorkom by hakkelaars en lewer dan ook in pleidooi aan ondersoekers om 'n noukeurige analise te maak van komponente gedragsvorme wanneer hakkel bestudeer word.

Die verklaring vir die verskynsel dat gevestigde hakkelaars nie dieselfde merkbare simptome vertoon nie, ${ }^{9}$ kan moontlik gesoek word in die primêre en sekondêre gedragsvorme waarin die hakkelmoment gedifferensieer kan word. Hierdie stelling steun Brutten en Shoemaker ${ }^{8}$ se siening dat die hakkelaar se self-gedifferensieerde, "onwillekeurige" gedrag in die primêre en sy "willekeurige" gedrag in die sekondêre kategorie val.

Meeste waarnemers stem saam dat hakkelgedrag met tydsverloop verander. Die gevestigde hakkelaar toon 'n groot verskeidenheid gespanne worstelings en morbiede emosionele reaksies wat min verband hou met sy vroeëre hakkelgedrag. Hakkelteorieë is dikwels in konflik met mekaar omdat hulle gebaseer is op die aard van die afwyking nadat dit alreeds ten volle ontwikkel het. Aangesien sekondêre gedrag verskillend ontwikkel by verskillende persone, sal navorsing wat gebaseer is op hierdie gedragsvorme lei tot verwarring. ${ }^{28}$ Dit dien as motivering waarom 'n gedragsvorm wat min of meer universeel by hakkelaars van alle ouderdomme voorkom, bestudeer moet word. Montgomery en Cooke ${ }^{21}$ noem dat woorddeelherhalings een van die universeel herkenbare simptome van hakkel is. Dit is een van die kerngedragsaspekte van hakkel, aangesien dit een van die primêre kenmerke is wat die ontwikkelende hakkelaar onderskei van die nie-hakkelaar. Daarom is woorddeelherhalings as studieterrein in hierdie navorsingsprojek geneem.

\section{Herhalingsgedrag by Hakkel}

Vlotheid word versteur wanneer 'n spraakeenheid deur die een of ander onderbreking geskei of verwyder word van die res van die uiting. ${ }^{6}$ Hierdie onderbrekings kan verskeie vorms aanneem soos bv. tussenwerpsels, herhalings (van klanke, lettergrepe, woorde en frases); hersienings, verlengings, gebroke woorde (pouses en eksplosiewe vrylatings) en selfs onvolledige of onvoltooide sinne. ${ }^{7,15,4}$ Herhalings is een van die basiese onderbrekings wat voorkom in die spraak van die hakkelaar en word gekenmerk deur 'n duplikasie van sekere spraakelemente. 


\section{Die Belang van Herhaling as Diagnostiese Kriterium}

Herhalings is 'n belangrike diagnostiese kriterium, aangesien hakkel herken kan word aan onderbrekings op morfemiese vlak, terwyl niehakkelende spraak gekenmerk word deur onderbrekings op supramorfemiese vlak. ${ }^{26,2 k}$ Dit is veral op twee gebiede wat hierdie kenmerkende gedrag nagevors is:

1. Die onderskeiding tussen aanvangshakkel en normale onvlotheid by kinders. Aanvangshakkelaars toon konsekwent lettergreep- en klankherhalings, asook klankverlengings, terwyl woord- en fraseherhalings

eerder kenmerkend is van die normale onvlotheidsperiode. ${ }^{10,32}$

2. Die verskil tussen hakkel en onvlotheid in nie-hakkelaars se spraak:

Veral Boehmler ${ }^{7}$ het hier gedui op die diagnostiese belang van lettergreep- en klankherhalings. Die feit dat Sheehan ${ }^{24}$ persentasiegewys bewys het dat sodanige herhalings by uitstek op die bestaan van hakkel dui (terwyl woord- en fraseherhalings meestal by nie-hak kelaars voorkom) beklemtoon nie alleen die diagnostiese waarde van hierdie gedragsvorm nie, maar onderskryf ook Wingate ${ }^{3.3}$ se siening dat herhalings die belangrikste deel van die kerngedrag van hakkel vorm. Ander outoriteite ondersk ryf ook hierdie bevindings en dui aan dat fraseherhalings, tussenwerpsels en pouses aanvaarbare onderbrekings van normale spraak
is. ${ }^{12,11,34}$

\section{Die Omvang en Aard van Herhalingsgedrag}

In die bestudering hiervan is dit eerstens nodig om ooreenstemmings te identifiseer. Relatiewe waardes en verskille sal eers daarna geïdentifiseer en duidelik word. ${ }^{31}$ Navorsingsresultate dui reeds op sekere ooreenstemmende eienskappe van herhalings bv. tipes en plek van voorkoms, sowel as sekere onderskeidende eienskappe bv. duur. ${ }^{3 l}$ Verder kan die aard van herhalingsgedrag ook reeds gekoppel word aan die erns van hakkel, ${ }^{18,}, 23$ Daar bestaan egter nog 'n dringende behoefte aan die bestudering van die aard van kerngedrag as diagnostiese kriterium. ${ }^{28}$ Kliniese bevindings beklemtoon reeds die volgende verskynsels by herhalingsgedrag as
onderskeidenheid:

Tempoverskille; onreëlmatigheid; gebrek aan oorgangsformante, gebruik van die schwa-vokaal; moontlike benaderingsgedrag; staking van lugvloei; staking van fonasie; skielike staking (teenoor geleidelike afname by die normale spreker); en kort pouses tussen herhalings. Dit is veral die eerste vyf wat dikwels as aanduidend van hakkel beskou word en nadere toeligting verdien. ${ }^{28}$

1. Die Tempo van Veelvuldige Woorddeelherhalings. Reel'matigheid in die tempo van uiting is kenmerkend van vlotspraak. So sal selfs in konstante tempo in die herhalings van nie-hak kelaars as aanvaarbare onderbrekings beskou kan word..$^{9}$ Dit is egter wanneer die tempo van herhalings merk baar verskil van die normale spoed van lettergreepuiting dat dit as aanduidend van hakkel beskou word ${ }^{28}$ Hoewel daar al navorsing gedoen is oor die duur van herhalings, ${ }^{24,31}$ is dit nog nie vergelyk met die duur van die ooreenstemmende vloteenhede in
spraakuiting nie. 
2. Die Onreëlmatigheid van Woorddeelherhalings. 'n Ander onderskeidende kenmerk van herhalingsgedrag by die hakkelaar is onreëlmatigheid. ${ }^{28,29}$ Van Riper meen dat hierdie veelvuldige onreëlmatige herhalings verband hou met die hakkelaar se onvermoë tot tydsberekening in sy spraakuiting. Beech en Fransella ${ }^{5}$ onderskryf hierdie teorie. Kliniese waarneming dui daarop dat hierdie soekende gedrag beïnvloed kan word deur faktore soos tydsdruk, wat hierdie onreëlmatigheid tot gevolg kan hê. ${ }^{26}$

3. Gebrek aan Oorgangsformante by Woorddeelherhalings. By vloeiende spraak word oorgangsvlotheid op die fonemiese vlak deur koartikulasie bewerkstellig." In die geval van herhalings by nie-hakkelende spraak kom die nodige oorgangsformante en lugvloei voor, terwyl beide ontbreek by herhalings van hakkelaars. ${ }^{28}$ Hierdie verskynsel is deur Stromsta ${ }^{25}$ deur middel van spektrogramme bewys.

in Verdere verwante verskynsel is Van $\operatorname{Riper}^{28}$ se vermoede dat die motoriese programmering belemmer word, omdat die hakkelaar sy artikulators tydens herhalings in 'n onnatuurlike posisie plaas. Sheehan ${ }^{24}$ bewys dat $43,6 \%$ van die herhalings verkeerde klanke bevat. Dit word verklaar op grond daarvan dat die hakkelaar dit te moeilik vind om die hele woord aan te durf en dus net woorddele probeer uitspreek wat die voorkoms van oorgangsformante onnodig maak. ${ }^{6}$

Verskeie skrywers beklemtoon dat hakkel as 'n fonetiese oorgangsprobleem beskou kan word. ${ }^{1,}$ "13 Dié beskouing verskaf ' $n$ verfyning in analise wat meer spesifiek die essensiële aard van die hakkelmoment spesifiseer. Dit is egter nie maklik waarneembaar nie en soms kan dit slegs deur middel van spektrogramme uitgelig word. ${ }^{25}$

4. Die Gebruik van die Schwa-Vokaal by Woorddeelherhalings. Die feit dat kliniese bevindings daarop dui dat die schwa-vokaal gebruik word tydens herhalingsgedrag word o.a. deur Sheehan, ${ }^{24} \operatorname{Van} \operatorname{Riper}^{28}$ en Montgomery en Cooke $\mathrm{e}^{20}$ verklaar.

Navorsing bewys egter dat alleenlik in $25 \%$ van gevalle die schwa gebruik word. ${ }^{20}, 24$ In hierdie gevalle is die verlangde formantoorgange en koartikulasie dus afwesig. $\mathrm{Na}$ aanleiding hiervan meen Montgomery en Cooke $^{20}$ dat die voorkoms van die schwa in die inisiële herhaling van veelvuldige herhalings wel Van $\operatorname{Ripe}^{28}$ se teorie in verband met soekende of benaderingsgedrag kan bevestig. Dit is duidelik dat verdere navorsing in verband met hierdie verskynsel noodsaaklik is.

5. Woorddeelherhalings as 'n vorm van Benadering tot die Verlangde Fonetiese Oorgang. By veelvuldige herhalings lyk dit, oppervlakkig beskou, asof dieselfde lettergreep oor en oor herhaal word. By nadere ondersoek blyk dit egter dat variërende artikulasieposisies voorkom, wat kan dui op soekende of benaderingsgedrag. ${ }^{30}$ Montgomery en Cooke ${ }^{20}$ kan benadering nie bevestig nie, omdat veelvuldige herhalings nie genoegsaam voorgekom het in hul proefpersone se spraak nie. Dit is dus 'n faset wat verdere navorsing vereis. 
Hoewel die term "lettergreepherhalings" meestal gebruik word in die literatuur, was dit nie geskik vir gebruik in hierdie ondersoek nie. "Lettergreepherhalings" sluit noodwendig ook een-lettergrepige woorde in en lg. herhalings kan ook as normale onvlotheid voorkom." Die term "woorddeelherhalings" is gekies om te verhoed dat verwarring by analise ontstaan. Dié term het in hierdie studie die betekenis van die herhaling van 'n lettergreep of kleiner eenheid van 'n woord. ${ }^{31}$ Om hierdie rede word "vlotlettergreep" ook vervang met die term "vloteenheid."

\section{Spraakanalise m.b.v. die Spektrograaf}

Hoewel daar nie 'n meer sensitiewe analiseerder van spraak is as die oor self nie,' word die klankspektrograaf as hulpmiddel tot ouditiewe analise gebruik, aangesien dit spraak na sigbare patrone verander wat as verwysing dien vir korrekte en foutiewe artikulatoriese bewegings in aaneenlopende spraak. ${ }^{16}$ Op spektrogramme kan daar ook afsonderlike sowel as aaneenlopende segmente waargeneem word.'

Daar word dus van 'n oudiovisuele analise gebruik gemaak aangesien beide modaliteite elk op eie wyse betekenisvolle leidrade aangaande spraakdimensies verskaf. Talle ondersoekers bevestig dat spektrografiese afwykings kan verskaf. ${ }^{20,25,22,28}$ angaande spraakkenmerke van spraak-

\section{METODE}

\section{HIPOTESE}

Die hipotese word gestel dat woorddeelherhalings by hakkel verskil van die ooreenstemmende vloteenheid en van nie-hakkelspraak in verskeie
opsigte nl.:

1. Die tempo van die herhalings verskil van die normale spoed van uiting van die ooreenstemmende vloteenheid.

2. Die hakkelaar se veelvuldige woorddeelherhalings vind plaas teen in onreëlmatige tempo.

3. Die verlangde oorgangsformante verskyn nie by die woorddeelherhalings nie.

4. Die schwa-vokaal word deur hakkelaars by woorddeelherhalings gebruik. 5. Die veelvuldige herhalings is 'n vorm van benadering tot die verlangde
oorgang.

\section{PROEFPERSONE}

Agttien proefpersone is gebruik. Hulle is geselekteer op grond van die teenwoordigheid van woorddeelherhalings in hul spraak. Ouderdom of geslag is me in ag geneem nie. Al die proefpersone was reeds vooraf deur 'n paneel spraakterapeute as hakkelaars gediagnoseer.

Volwassenes is ook gebruik, aangesien beide kinders en volwassenes wat as hakkelaars gediagnoseer is, se spraak proporsioneel meer woorddeel'nerhalings toon. ${ }^{7}$ 
Die voorwaarde was dus dat die proefpersone hierdie universele kerngedrag moes toon. Geen ander spraakverskynsels of gedragsvorme wat by individuele proefpersone mag voorgekom het, het 'n rol gespeel nie.

Proefpersone:

Ouderdomme (jare) Manlik Vroulik

$\begin{array}{lll}0-5 & 1 & \\ 5-10 & 3 & 1 \\ 11-15 & 2 & 2 \\ 16-20 & 1 & \\ 20-25 & 4 & \\ \text { Bo } 25 & 3, & 1\end{array}$

APPARAAT

Bandopnames is gemaak in 'n klankdigte kamer met 'n Nagra 111 No. $\mathrm{BH} 67884$ bandopnemer en mikrofoon. Vir die ontlokking van spontane spraak, is T.A.T. en C.A.T. kaarte gebruik. ${ }^{15}$

Spektrogramme is gemaak met 'n Voice Identification Incorporated Model 700.

\section{PROSEDURES}

Ses-minuut opnames van spontane spraak is van die agttien hakkelaars gemaak volgens die voorskrifte van Johnson, Darley en Spriestersbach ${ }^{15}$ - "The Job Task". Hierdie prosedures is ook aangepas vir kinders. Die T.A.T. en C.A.T.-kaarte is gebruik vir spraakmonsters wat meer emosionele betrokkenheid van die sprekers geverg het.

Die maak van spektrogramme:

Altesaam 305 Spektrogramme is van die herhalingsgedeeltes gemaak. Betroubare prosedures is gebruik om die spektrogramme te maak en te analiseer. Hier kan verwys word na hulp en aanwysings van Kopp en Green, ${ }^{16}$ Kopp, Kopp en Angelocci; ${ }^{17}$ Potter, Kopp en Kopp ${ }^{22}$ se geskrifte.

Om te bepaal of die woorddeelherhalings reëlmatig of onreëlmatig plaasvind. Dit het berus daarop dat die duur van die herhalingseenhede, asook die duur van die vloteenheid met behulp van 'n konstantheidsfaktor bereken is. Die duurverskil is dan in vier kategorieë ingedeel.

Om te bepaal of die verlangde oorgangsformante by die eerste of enigste herhalingseenheid voorgekom het. In hierdie geval is gebruik gemaak van die eerste, tweede en derde formantposisies; die bandopnames (ouditiewe modaliteit) en die formantpatrone, om te bepaal of die verlangde oorgangsformant definitief, onwaarskynlik of glad nie voorgekom het nie. Die formantpatrone is in ag geneem, omdat klanke wat gekombineer word mekaar beïnvloed. Dit word getoon in die oorgange van hierdie formantpatrone. Hierdie oorgangsbewegings is belangrik by die herkenning van geproduseerde klanke en dit moet dus ook in ag geneem word by beoordeling. ${ }^{22}$ 
Om te bepaal of die schwa-vokaal by die eerste of enigste herhalingseenheid gebruik is. Hierdie aspek is volgens 'n drie-punt skaal beoordeel. Die beoordeling was gegrond op die formantgebiede sowel as die ouditiewe beeld. Die koëffisiënt van die voorkoms van hierdie verskynsel by die verskillende kategorieë van elke proefpersoon afsonderlik en ook die somtotaal van elke kategorie is bereken.

Om te bepaal of die opeenvolgende herhalings van elke spraakpoging'n benadering is tot die verlangde artikulatoriese oorgang. Hierdie aspek is ook volgens 'n drie-punt skaal beoordeel, gegrond op die posisies van die spil (tweede formantbalk) van die herhalings- en vloteenhede. Die spil verander die meeste in posisie en die spil van klanke koppel ook op 'n bestendiger wyse. Dit is dus die belangrikste formant om dop te hou by die identifisering van klankpatrone en kombinasies. ${ }^{22}$ Die koëffisiënt van die voorkoms van hierdie verskynsel by die verskillende kategorieë van elke proefpersoon afsonderlik en ook die somtotaal van elke kategorie is bereken. Deur die toepassing van 'n toets vir 'n verhouding is daar by al vyf bogenoemde tabulerings bepaal of een van die kategorieë statisties betekenisvol verskil het van die ander. Dié waarde word genoem die $/ z /$.
waarde.

\section{RESULTATE EN BESPREKING}

Tabel I bevat die ontleding van 315 spraakpogings, waarvan $41(13 \%)$ geklassifiseer is as om van dieselfde duur te wees. By $274(87 \%)$ het die duur verskil van dié van die ooreenstemmende vloteenheid. By 18 gevalle $(5,7 \%)$ was die duur van die herhalingseenheid $16-31$ msek. korter en by $35(11 \%) 16-31$ msek. langer as dié van die vloteenheid. 107 Gevalle het 'n duur van meer as $31 \mathrm{msek}$. korter en $114(36 \%)$ 'n duur van meer as 31 msek. langer getoon. 'n Totaal van $70 \%$. 'n Afwyking word betekenisvol op die $5 \%$ betekenispeil geneem indien
die $/ z /$ waarde $\geq 1,96$.

Dit word betekenisvol op die $1 \%$ peil geneem indien die $/ z /$ waarde $\geq 3,29$. Dit dui op 'n uiters betekenisvolle verskil. In dié ontleding is ' $n$ /z/-waarde van 13,072 bereken, en daar is dus op 'n $0,1 \%$ betekenispeil gevind dat die woorddeelherhalings in tempo baie betekenisvol verskil het van die ooreenstemmende vloteenhede. Ook is gevind dat hierdie duurverskille groot was, aangesien die duurverskille by $70 \%$ gevalle meer as $31 \mathrm{msek}$. was. Hoe groter die verskil in duur tussen die herhalingseenheid en die vloteenheid, hoe meer opmerklik is die abnormaliteit, en dit is moontlik waarom woorddeelherhalings uitgesonder word deur die luisteraar. ${ }^{28}$ Daar is nie 'n statisties betekenisvolle verskil gevind tussen herhalingseenhede wat van korter en van langer duur was nie, aangesien $\mathrm{n} / \mathrm{z}$ /-waarde van 1,39 bereken is. Montgomery en Cooke ${ }^{20}$ skryf hierdie

The South African Journal'of Communication Disorders, Vol. 25. 1978 


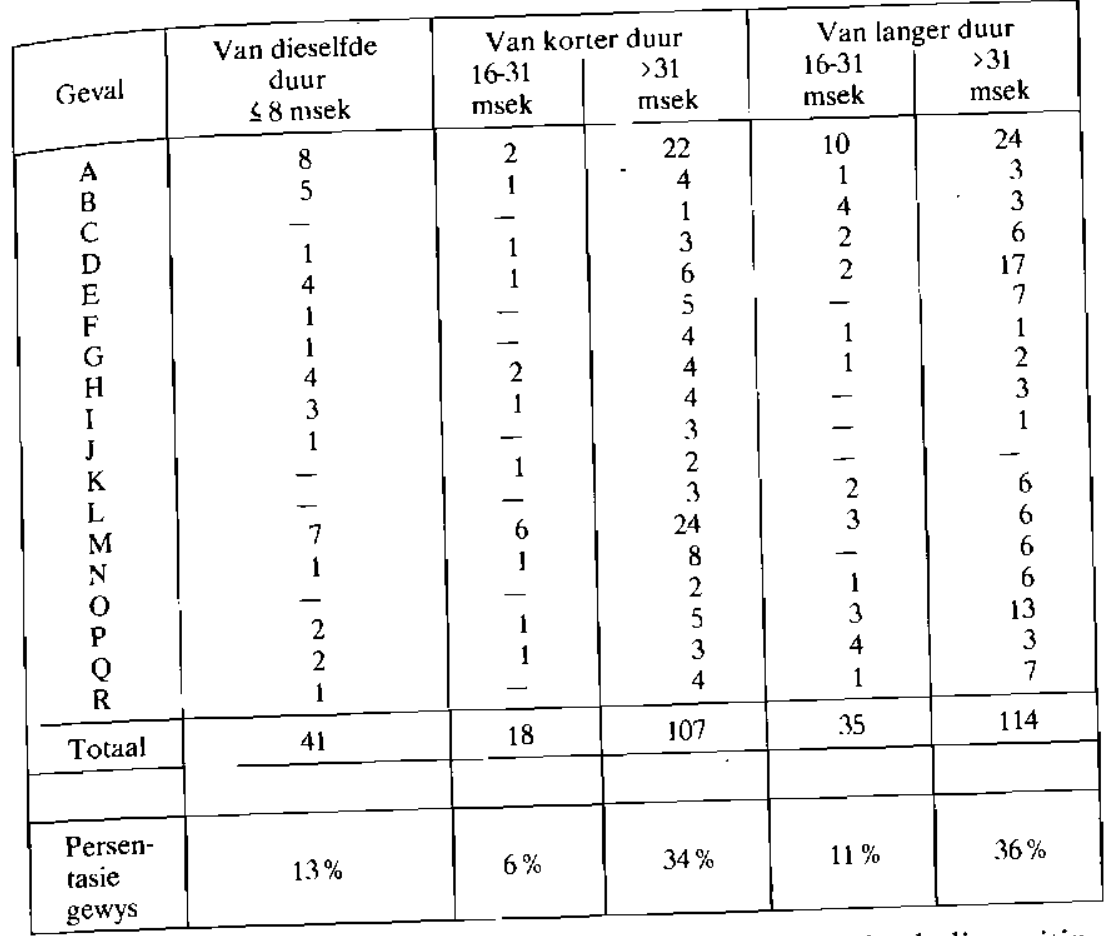

TABEL 1 'n Vergelyking van die tempo van die eerste herhalingsuiting met die uiting van die ooreenstemmende vloteenheid.

verskil toe aan die duur van die inisiële konsonant. Hulle het bevind dat die duur van hierdie konsonant van die gehakkelde woord 20 msek. of meer langer was as dié van die ooreenstemmende konsonant van die vlotwoord. Hierdie bevindings stem ooreen met die hipotese wat aanvanklik gestel is.

Bespreking van resultate soos getabuleer in Tabelle 11, III en IV By 76 gevalle het twee herhalings per spraakpoging voorgekom, 36 is deur drie herhalings voorafgegaan en 17 deur vier. As gevolg van hierdie variasie moes die groepe afsonderlik ontleed word. By die groepe met drie en vier herhalings per spraakpoging is die verskil bepaal tussen dié met die langste en dié met die kortste duur.

By die spraakpogings wat deur twee, sowel as dié wat deur drie woorddeelherhalings voorafgegaan is, is daar op die $0,1 \%$ betekenispeil gevind dat daar' $n$ beduidende duurverskil tussen die herhalingseenhede voorgekom het. By eg. is ' $\mathrm{n} / \mathrm{z} /$-waarde van 8,603 bereken en by $1 \mathrm{~g} .5,833$. Daar is egter nie 'n statisties betekenisvolle verskil verkry tussen die totale aantal wat van korter duur was en dié wat van langer duur was nie. $(/ \mathrm{z} /$-waarde $=0,167)$.

Alhoewel daar te min gevalle voorgekom het waar vier herhalings die vlotuiting voorafgegaan het, om statisties te ontleed, blyk dit dat dieselfde neiging as by die vorige gevalle voorkom.

Die Suid-Afrikuanse Tydskrif vir Kommunikasieafwykings, Vol. 25. 1978 


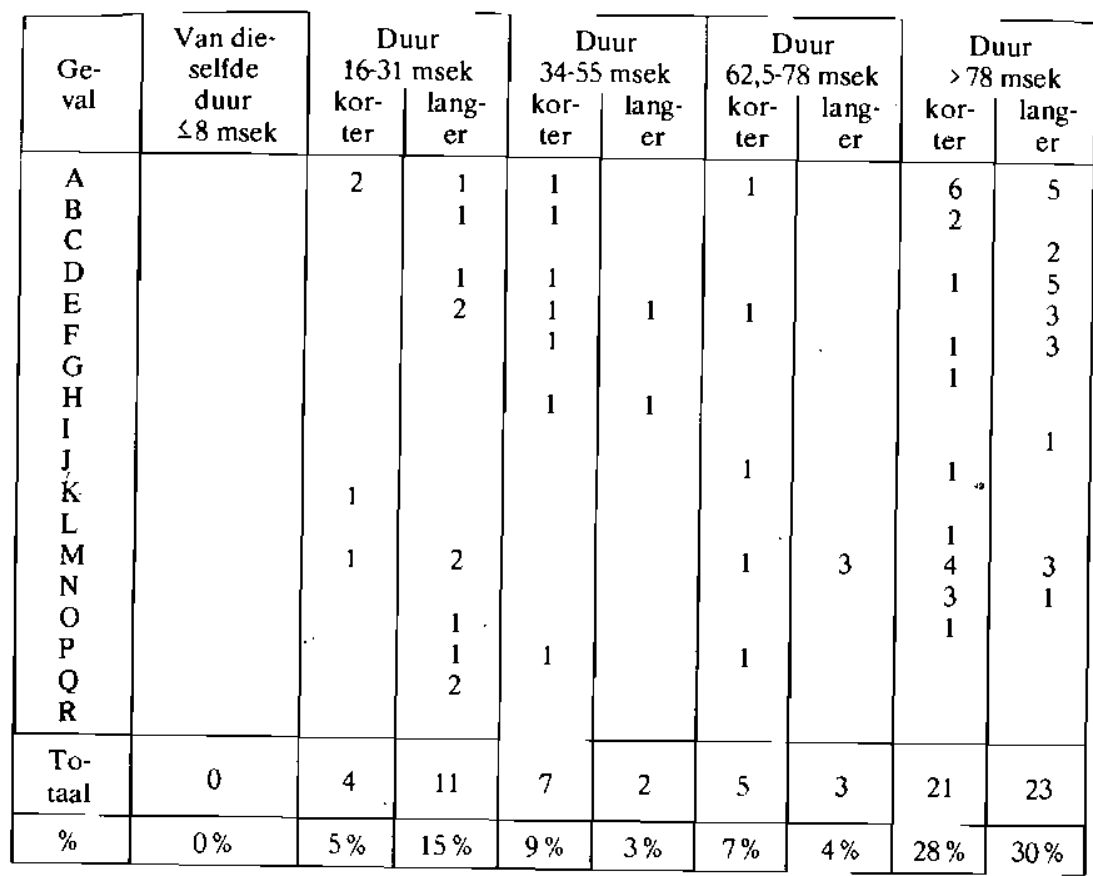

TABEL II 'n Vergelyking van die duur van woorddeelherhalings by gevalle waar daar twee herhalings per spraakpoging voorgekom het.

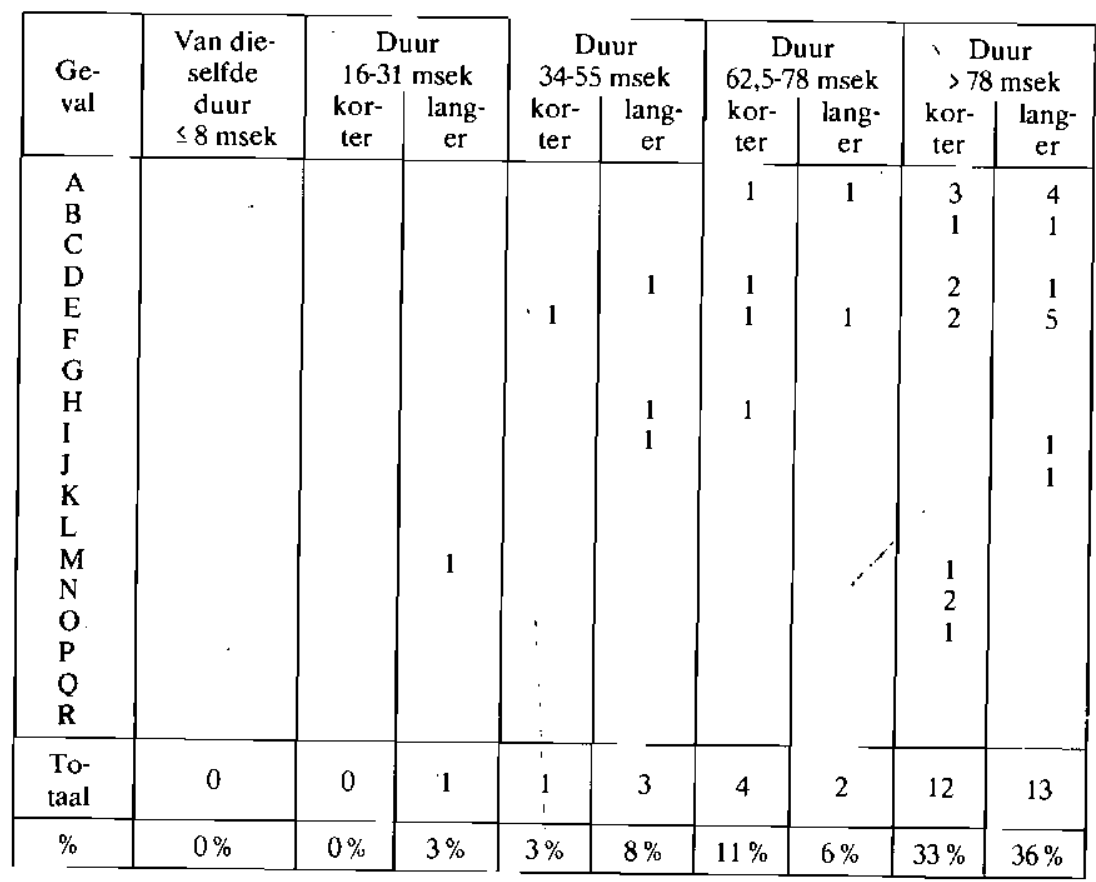

TABEL III 'n Vergelyking van die duur van woorddeelherhalings by gevalle waar daar drie herhalings per spraakpoging voorgekom het.

The South African Journal of Communication Disorders. Vol. 25, 1978 


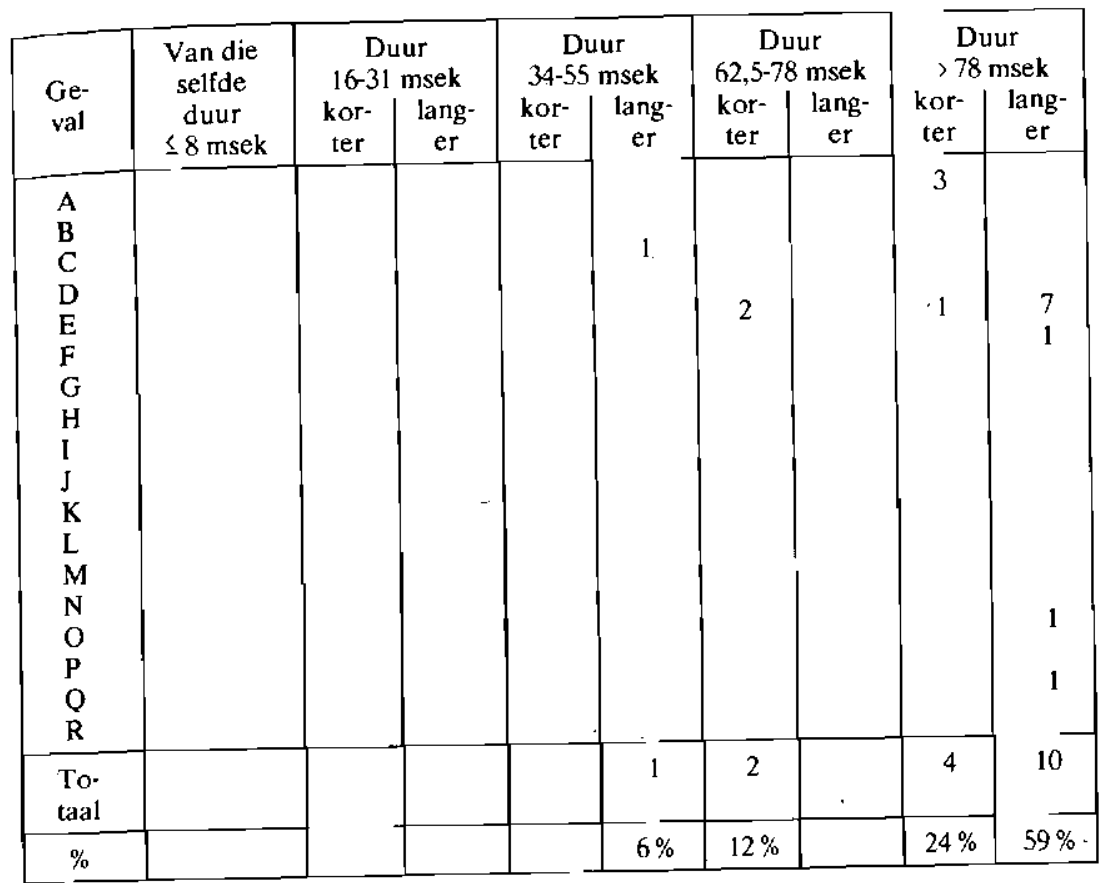

TABEL IV ' $n$ Vergelyking van die duur van woorddeelherhalings by gevalle waar daar vier herhalings per spraakpoging voorgekom het.

Uit Tabelle II en III blyk dit dat by die meeste gevalle nl. $58 \%$ en $69 \%$ gevalle onderskeidelik, die duurverskil meer as 78 msek. was. By alle gevalle was daar 'n duurverskil van meer as $16 \mathrm{msek}$. Die veelvuldige herhalings van hakkelaars word dus opmerklik onreëlmatig geuiter, wat van Riper se kliniese indruk van hakkelspraak bevestig i.t.m. die normale onvlothede van nie-hakkelaars wat glad, reëlmatig en teen dieselfde tempo as die res van hul lettergrepe geuiter word. ${ }^{28}$ Montgomery en Cooke het ook by $62 \%$ van pare monsters wat hulle ontleed het 'n verskil in tempo van produksie opgemerk..$^{20} \mathrm{Dit}$ bevestig ook die hipotese wat aanvanklik gestel is.

Die voorkoms al dan nie van die verlangde oorgangsformant by die eerste of enigste woorddeelherhaling wat die vlotuiting voorafgaan (Sien Tabel V).

Daar is gevind dat die verlangde oorgangsformant by $30 \%$ gevalle wel voorgekom het, by $64 \%$ was dit onwaarskynlik en by $6 \%$ was die moontlikheid nie uitgesluit dat dit wel die verlangde oorgang was nie. Statisties is op die $0,1 \%$ betekenispeil gevind dat dit onwaarskynlik is dat die oorgangsformant van die eerste of enigste woorddeelherhaling ooreenstem met die verlangde formant van die vloteenheid, aangesien ' $n$ /z/-waarde van 5,99 bereken is. Dit bevestig Van Riper se hipotese. ${ }^{28}$ Hierdie bevinding word ook nog onderskryf deur warnemings van

Die Suid-Afrikaanse Tydskrif vir Kommunikasieafwykings. Vol. 25, 1978 


\begin{tabular}{|c|c|c|c|}
\hline GEVAL & JA & MOONTLIK & ONWAARSKYNLIK \\
\hline A & 4 & 3 & 58 \\
B & 3 & 1 & 9 \\
C & 1 & 0 & 7 \\
D & 1 & 0 & 12 \\
E & 5 & 0 & 24 \\
F & 6 & 2 & 4 \\
G & 4 & 0 & 3 \\
H & 9 & 0 & 4 \\
I & 1 & 2 & 8 \\
J & 1 & 1 & 3 \\
K & 1 & 1 & 1 \\
L & 1 & 0 & 10 \\
M & 32 & 0 & 15 \\
N & 8 & 2 & 6 \\
O & 0 & 1 & 8 \\
P & 10 & 3 & 9 \\
Q & 4 & 1 & 9 \\
R & 3 & 1 & $64 \%$ \\
\hline Totaal & 94 & 18 & $9 \%$ \\
\hline$\%$ & $30 \%$ & $6 \%$ & 11 \\
\hline
\end{tabular}

TAB̈EL $\vee$ Die voorkoms van die verlangde oorgangsformant by die eerste of enigste woorddeelherhaling wat die vlotuiting voorafgaan.

Agnello ${ }^{1}$ en Montgomery en Cooke. ${ }^{20}$ Dit is dus moontlik dat die formantafwykings reflekteer dat die konsonant van die gehakkelde woord geproduseer was met 'n abnormale stand van die artikulasie organe. Daarom is die artikulatoriese (en dus akoestiese) verloop vanaf hierdie stand na dié nodig vir die produksie van die verlangde vokaal ooreenstemmend versteur. Die outeurs hipotetiseer dus dat die abnormale formantoorgange die gevolg is van afwykende artikulasie van die konsonant eerder as wat dit die gevolg is van foutiewe oorgangsdinamika. ${ }^{20}$ Daar word ook weer verwys na die bevindinge van Stromsta, ${ }^{25}$ aangaande die gebrek aan formantoorgange as diagnostiese middel vir die identifisering van hakkelaars. Hierdie bevinding bevestig die hipotese wat aanvanklik gestel is.

Aangaande die gebruik van die schwa-vokaal deur hakkelaars by hul woorddeelherhalings.

Daar is gevind dat by $22 \%$ gevalle die schwa-vokaal wel geproduseer is, wat goed ooreenstem met Montgomery en Cooke se bevinding van $25 \%{ }^{20}$ Verder was dit by $51 \%$ van gevalle onwaarskynlik, terwyl daar by $27 \%$ wel die moontlikheid bestaan het dat die schwa geproduseer is. Statisties is op die $0,1 \%$ betekenispeil gevind dat dit onwaarskynlik is dat die schwa-vokaal gebruik is by die eerste of enigste woorddeelherhalings van hierdie hakkelaars. Hierdie bevinding is teenstrydig met die verwagte resultate asook met Van Riper se kliniese indruk: $:^{2 \mathrm{~K}}$ Almost universally the schwa vowel can be heard in the stutterer's abortive speech attempts.

Hierdie teenstrydigheid kan verklaar word aan die hand van die feit dat 


\begin{tabular}{|c|c|c|c|}
\hline GEV AL & JA & MOONTLIK & ONWAARSKYNLIK \\
\hline A & 21 & 15 & 28 \\
B & 2 & 2 & 7 \\
C & 3 & 2 & 2 \\
D & 4 & 1 & 8 \\
E & 11 & 11 & 4 \\
F & 2 & 3 & 1 \\
G & 0 & 1 & 6 \\
H & 0 & 2 & 11 \\
I & 4 & 1 & 5 \\
J & 2 & 0 & 2 \\
K & 1 & 1 & 0 \\
L & 3 & 1 & 6 \\
M & 2 & 12 & 30 \\
N & 1 & 5 & 4 \\
O & 1 & 4 & 14 \\
P & 4 & 6 & 3 \\
Q & 2 & 6 & 147 \\
\hline R & 1 & 4 & $51 \%$ \\
\hline Totaal & 64 & 77 & -1 \\
\hline$\%$ & $22 \%$ & $27 \%$ & \\
\hline
\end{tabular}

TABEL VI ' $n$ Beoordeling van die voorkoms van die schwa-vokaal by die eerste of enigste woorddeelherhalings van spraak pogings waar 'n neutrale vokaal nie verlang word nie.

\begin{tabular}{|c|c|c|c|}
\hline GEVAL & JA & MOONTLIK & ONWAARSKYNLIK \\
\hline A & 2 & 0 & 4 \\
B & 0 & 0 & 5 \\
C & 0 & 0 & 3 \\
D & 0 & 0 & 4 \\
E & 0 & 0 & 4 \\
F & 0 & 0 & 4 \\
G & 1 & 0 & 0 \\
H & 1 & 0 & 3 \\
I & 0 & 2 & 2 \\
J & 0 & 1 & 2 \\
L & 0 & 0 & 1 \\
M & 0 & 0 & 5 \\
N & 1 & 0 & 4 \\
O & 0 & 0 & 2 \\
P & 0 & 1 & 0 \\
\hline P & 1 & 0 & 48 \\
\hline Totaal & 0 & 0 & $83 \%$ \\
\hline$\%$ & $10 \%$ & 4 & \\
\hline
\end{tabular}

TABEL VII Die voorkoms van benaderingsgedrag.

Die Suid-Afrikuanse Tydskrif vir Kommunikasieafwykings, Vol. 25, 1978 
die vorige bewerings grootliks gebaseer was op kliniese indrukke as 'n deeglike analise. Hierdie indrukke reflekteer die natuurlike neiging van 'n luisteraar wanneer hy vokaalsegmente van kort duur teenkom, soos by deelwoordherhalings of oor die algemeen wanneer onsekerheid teengekom word, om tot die gevolgtrekking te kom dat die neutrale vokaal geuiter is. ${ }^{20}$

\section{Die Voorkoms van Benaderingsgedrag}

By $83 \%$ het dit geblyk dat dit onwaarskynlik is dat daar van benaderingsgedrag sprake is. By $69 \%$ het definitiewe benaderingsgedrag voorgekom en by $7 \%$ gevalle was dit moontlik. T.s.v. die relatief min spraakpogings met genoeg woorddeelherhalings om hierdie eienskap te ondersoek, soos die geval met Montgomery en Cooke ${ }^{20}$ se ondersoek, is daar statisties op die $0,1 \%$ betekenispeil gevind dat dit onwaarskynlik is dat die veelvuldige herhalings 'n wyse van benadering tot die verlangde oorgang van die vlotuiting is.

Hierdie bevinding korreleer dus nie met die hipotese wat gestel is nie en ook nie met Van Riper se kliniese indruk nie..$^{2 B}$

\section{GEVOLGTREKKINGS}

Buiten die voorkomsfrekwensie van onderbroke woorde, is daar ook nog ander eienskappe waarvolgens 'n diagnose van hakkel gemaak kan word. Die bevinding van hierdie studie is dat die tempo waarteen hakkelherhalings geuiter word verskil van dié van normale onvlothede en ook dat eg. opmerklik onreëlmatig is. Kliniese waarnemings het getoon dat tydsberekening 'n belangrike faktor is in die voorkoms van hakkel. So bv. beïnvloed tydsdruk die hakkelaar se spraak. Die hakkelaar vertoon soekende gedrag-gedrag wat daarop gerig is om die regte tydsberekening vir woorduiting te bewerkstellig. ${ }^{26} \mathrm{Dit}$ is dus moontlik dat hakkel ontstaan as gevolg van 'n biologiese onvermoë om op morfemiese vlak motoriese patrone temporaal te bemeester. Aangesien daar geen reëlmatigheid ten opsigte van tempoverskille voorgekom het nie, word die indruk geskep dat hierdie gedrag onwillekeurig is, soos Webster en Brutten dit ook stel. ${ }^{30}$

Hoewel daar gevind is dat die verlangde oorgangsformante nie by die woorddeelherhalings van hakkelaars voorkom nie, is dit egter ook nie die schwa-vokaal wat gebruik word nie. Die veelvuldige herhalings is ook nie 'n poging tot benadering van die verlangde oorgang nie. Die artikulatoriese model voorgestel deur Henke ${ }^{19}$ kan moontlik gebruik word om die abnormale temporale aspek en die ongewensde oorgangsformant waarmee die hakkelspasma geïnisieer word, met mekaar in verband te bring. Die toevoer van die model is 'n string foon-grootte segmente wat elk gespesifiseer is i.t.v. 'n stel artikulatoriese mikpunte. Laasgenoemde stel "n beperkte reeks saam wat onderskeidelik gevarieer word in tyd. Hulle is vorme en posisies van die artikulators. Hoewel die artikulators na hierdie spesifieke mikpunte beweeg, mag hulle moontlik nie bereik word nie. Die posisies wat bereik word hang af van die-artikulasiestande wat 
voorheen deur die artikulators ingeneem is en van die tydreëling van opeenvolgende toevoerings. Henke stel ook 'n vooruitbeskouing van toekomstige toevoereenhede voor, wat 'n verwagting van koartikulasie van sekere eienskappe toelaat, wanneer dit nie in konflik is met die gespesifiseerde mikpunte van meer onmiddellike eenhede nie.

Daar kan dus tot die gevolgtrekking gekom word dat woorddeelherhalings nie alleen 'n essensiële eienskap is wat algemeen by hakkelaars opgemerk word nie, ${ }^{28}$ maar dat dit ook sekere distinktiewe eienskappe bevat wat veroorsaak dat die luisteraar dit juis uitsonder as hakkelgedrag.

\section{DIE WAARDE VAN DIE STUDIE EN MOONTLIKE AANBEVELINGS}

Spraakkenmerke wat van belang is vir die differensiaaldiagnose tussen hakkelspraak en normale onvlothede is deur hierdie studie bevestig.

Naamlik dat woorddeelherhalings onreëlmatig geuiter word en nie teen dieselfde tempo as die vlotuiting nie, en ook die afwesigheid van die verlangde oorgangsformant by die inisiële herhaling. Hierdie was vroeër slegs kliniese indrukke. ${ }^{28,25}$ Dit impliseer terapeuties dat daar met die afbraak van die hiërargiese gedragsvorme van hakkelaars begin moet word by die willekeurige sekondêre gedrag. Aangesien die primêre gedragsvorme onwillekeurig is ${ }^{30}$ mag die volgende tegnieke van waarde wees: Tegnieke wat ontspanning meebring onder andere Johnson se bonstegniek, verlengde spraak en ligte kontakte deur die artikulators." Metodes wat die hakkelaar met die tydsberekening van spraakpogings help, kan ook met sukses in terapie aangewend word. ${ }^{2,3,27}$

Die volgende aspekte mag interessant wees om verder na te vors: Aangesien dit nie die schwa is wat oor die algemeen deur hakkelaars gebruik word in hulle inisiële herhalings nie, kan dit van waarde wees om te bepaal watter klank dan wel die meeste gebruik word.

Navorsing word benodig aangaande verdere aspekte van belang vir differensiaaldiagnose ${ }^{28} \mathrm{nl}$ : of lugvloei by hakkelherhalings wel onderbreek word en of skielike fonatoriese stakings dit vergesel; of pouses by normale lettergreepherhalings baie korter is as dié van gehakkelde herhalings. Daar kan ook nog dieper ingegaan word op die kwessie van benadering.

Dit mag interessant wees om te bepaal of die fonetiese samestelling van die vloteenheid 'n rol speel by die korter of langer duur van die herhalingseenheid. Daar is bevind dat daar wel tot duidelike resultate en gevolgtrekkings gekom kan word deur 'n enkele komponente gedragsvorm van die konglomeraat te selekteer en dit te analiseer. ${ }^{30}$ Daar is ook bevind dat spektrografie nie alleenlik 'n waardevolle hulpmiddel is by eksperimentele ondersoek nie, maar dat dit ook van diagnostiese belang is om spektrografiese ontledings van spraakmonsters te maak. Sodoende word spraakkenmerke van spraakafwykings uitgelig, wat nie bloot deur die ouditiewe bepaal kan word nie. Hierdie siening word gesteun en bevestig deur Stromsta, ${ }^{25}$ Van Riper, ${ }^{28}$ Montgomery en Cooke ${ }^{20}$ en Potter, Kopp en Kopp. ${ }^{22}$ 


\section{VERWYSINGS}

1. Agnello, J.G. (1975): Measurement Procedures in Speech, Hearing and Language, University Park Press.

2. Barber, V. (1939): Chorus Reading as a Distraction in Stuttering, Studies in the Psychology of stuttering XV, J. Speech Dis.. 4, 371-383.

3. Barber, V. (1940): Rhythm as a Distraction in Stuttering, Studies in the Psychology of Stuttering XVI, J. Speech Dis., 15, 29-42.

4. Barr, H. (1940): A quantitative Study of the Specific Phenomena Observed in Stuttering, J. Speech Dis., 5, 277-280.

5. Beech, H.R. en Fransella, F. (1966): Research and Experiment in Stuttering, Pergamon Press, Oxford.

6. Bloodstein, O. (196i): The Development of Stuttering III. Theoretical and Clinical Implications, J. Speech Hear. Dis., 26, Nr. 1, 67-81.

7. Boehmler, R.M. (1958): Listener Responses to Non-Fluencies, $J$. Speech Hear. Res., 1, 132-141.

8. Brutten, G. en Shoemaker, D. (1971): A Two factor Learning Theory of Stuttering. In Handbook of Speech Pathology and Audiology, Travis, L. (Ed.). Appleton Century Crofts, New York, bls. 1035 1072.

9. Dalton, P. en Hardcastle, W.J. (1977): Disorders of Fluency and their effects on Communication, Billing and Sons Ltd London.

10. Davis, D.M. (1939): The Relation of Repetition in the Speech of Young Children to certain Measures of Language Maturity and Situational Factors, Part I, J. Speech Dis., 4, 308-318.

11. Flanagan, J.L. (1972): Speech Analysis Synthesis and Perception, 2nd Edit. Universitätsdrückerei, Würzburg.

12. Froeschels, E. (1952): The Significance of Symptomatology for the Understanding of the Essence of Stuttering, Folia Foniatrica, IV, 217-230.

13. Helmreich, H.G. en Bloodstein, O. (1973): The Grammatical Factor in Childhood Disfluency in Relation to the Continuity Hypothesis, $J$. Speech Hear. Res., 16, 731-738.

14. Jakobson, R., Fant, G. en Halle, M. (1963): Preliminaries to Speech Analysis: The Distinctive Features and their Correlates, M.I.T. Press.

15. Johnson, W., Darley, F.L. en Spriestersbach, D.C. (1963): Diagnostic Methods in Speech Pathology, Harper \& Row, New York.

16. Kopp, G. en Green, H. (1948): Visible Speech, Volta.Review, Feb., 60-62.

17. Kopp, G.A., Kopp, H.G., Angelocci, A. (1967): Visible Speech Manual, Wayne State University Press, Detroit.

18. Minifee, F.D. en Cooker, H.S. (1964): A Dysfluency Index, J. Speech Hear. Dis., XXIX, 189-193.

19. Moll, K.L. en Daniloff, R.G. (1971): Investigation of the Timing of Velar Movements during Speech, Part 2, J. Acoustical Soc. America, 50 , Nr. 2. 
20. Montgomery, A.A. en Cooke, P.A. (1976): Perceptual and Acoustical Analysis of Repetitions in Stuttered Speech, J. Commun. Dis. 9, 317330.

21. Peters, R. en Giles, M. (1965): Stuttering in Relation to Syntactical and Phonemic Structure of the English Language, Kongresverslag van die Internasionale Vereniging vir Logopedie en Foniatrie, 11, 321-323.

22. Potter, R.K., Kopp, G.A., Kopp, H.G. (1966): Visible Speech, Dover Publications Inc., New York.

23. Sander, E.K. (1963): Frequency of Syllable Repetition and Stutter Judgements, J. Speech Hear. Res., VI, 19-30.

24. Sheehan, J.G. (1974): Stuttering Behaviour: A Phonetic Analysis., J. Commun. Dis., 7, 193-212.

25. Stromsta, C. (1965): A Spectrographic Study of Dysfluencies labelled as Stuttering by Parents, Kongresverslag van die Internasionale Vereniging van Logopedie en Foniatrie, II, 317-318.

26. Uys, I.C. (1973): 'n Biologies-Gefundeerde Hipotese in verband met die Ontstaan van Hakkel, Tydskrif van die Suid-Afrikaanse Vereniging vir Spraak en Gehoorheelkunde, 20, Des. 47-58.

27. Van Dantzig, M. (1940): Syllable-Tapping, A New Method for the help of Stammerers, J. Speech Dis., 5, 127-131.

28. Van Riper, C. (1971): The Nature of Stuttering, Prentice Hall Inc.

29. Van Riper, C. (1972): Speech Correction: Principles and Methods, Prentice-Hall Inc. 5th Edit.

30. Webster, L. en Brutten, G. (1972): An Audiovisual Behavioral Analysis of the Stuttering Moment, Behaviour Therapy, 3, 555-560.

31. Wingate, M.E. (1976): Stuttering Theory and Treatment, Irvington Publishers Inc., New York.

32. Wingate, M.E. (1964): A Standard Definition of Stuttering, J. Speech Hear. Dis., XXIX, 484-489.

33. Wingate, M.E. (1969): Stuttering as Phonetic Transition Defect, $J$. Speech Hear. Dis., XXXIV, 107-108.

34. Yairi, E. en Clifton, N. (1972): Dysfluent Speech Behaviour of Preschool Children, High School Seniors, and Geriatric Persons, J. Speech Hear. Res., 15, 714-719. 


\section{Aids for}

- the development of perception

- the acquisition of speech and language skills

- the improvement of motor co-ordination

\section{Plus}

- helpful texts for therapists

- educational toys, books and equipment

- records for auditory training

- catalogues on request

- large variety of tests available

\section{New Arrivals:}

- Learning to Listen

- Two sound lottos

- "Listen what is that?"

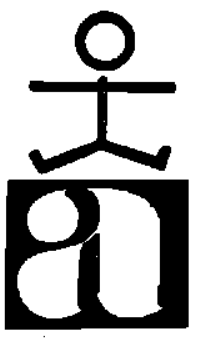

\section{PLAY AND SCHOOLROOM}

8 Tyrwhitt Avenue, Rosebank (adjoining the Constantia Cinema)

Telephones: 788-1304

P.O. Box 52137, Saxonwold, 2132 